\title{
Nocardia xishanensis sp. nov., a novel actinomycete isolated from soil
}

Correspondence

Zhiheng Liu

zhliu@sun.im.ac.cn

\author{
Jianli Zhang, ${ }^{1}$ Zhiheng Liu ${ }^{2}$ and Michael Goodfellow ${ }^{3}$ \\ ${ }^{1}$ School of Life Science and Technology, Beijing Institute of Technology, Beijing 100081, \\ People's Republic of China \\ ${ }^{2}$ State Key Laboratory of Microbial Resources, Institute of Microbiology, Chinese Academy of \\ Sciences, Beijing 100080, People's Republic of China \\ ${ }^{3}$ School of Biology, University of Newcastle, Newcastle upon Tyne NE1 7RU, UK
}

\begin{abstract}
The taxonomic position of a soil isolate, strain $276^{\top}$, was established using a polyphasic approach. The organism showed a range of chemical and morphological properties consistent with its classification in the genus Nocardia. An almost complete 16S rRNA gene sequence determined for the strain was aligned with corresponding sequences of representatives of the genus Nocardia and related taxa using three tree-making algorithms. The organism formed a distinct phyletic line within the evolutionary radiation occupied by the genus Nocardia and was most closely related to the type strain of Nocardia abscessus. However, the two strains shared a low DNA-DNA relatedness value and were readily distinguished using a combination of phenotypic properties. The combined genotypic and phenotypic data show that strain $276^{\top}$ should be assigned to the genus Nocardia as a novel species. The name proposed for this new taxon is Nocardia xishanensis sp. nov. The type strain is $276^{\top}\left(=\mathrm{CGMCC} 4.1860^{\top}=\mathrm{JCM} 12160^{\top}\right)$.
\end{abstract}

The genus Nocardia has had a long and troubled taxonomic history but is now well defined due to the application of chemotaxonomic, molecular genetic and numerical phenetic methods (Goodfellow et al., 1999). At the time of writing the genus contains 37 species with validly published names, most of which have been described within the last 5 years. Members of many of the novel species have been implicated as agents of human disease (Hamid et al., 2001, Yassin et al., 2000, 2001a, b, 2003; Kageyama et al., $2004 a, b)$ though it is evident that nocardial diversity is grossly underestimated in environmental samples, notably soil (Orchard \& Goodfellow, 1980; Wang et al., 1999; Maldonado et al., 2000). Nocardiae form part of the soil microflora and play a role in the turnover of organic matter (Orchard, 1981); there is also evidence that some strains produce secondary metabolites of potential industrial value (Isik et al., 1999; Kinoshita et al., 2001). The present investigation was designed to clarify the taxonomic position of a soil isolate, strain $276^{\mathrm{T}}$, using a polyphasic approach.

Strain $276^{\mathrm{T}}$ was isolated on modified Sauton's agar plate (Mordarska et al., 1972) that had been incubated at $28^{\circ} \mathrm{C}$ for 8 days following inoculation with a suspension of a soil sample collected from Xishan Mountain, Beijing, China. The isolate was maintained on modified Sauton's agar slants at $4{ }^{\circ} \mathrm{C}$ and as suspensions of mycelial fragments in

The GenBank/EMBL/DDBJ accession number for the 16S rRNA gene sequence of strain $276^{\top}$ is $A Y 333115$. glycerol $(20 \%, \mathrm{v} / \mathrm{v})$ at $-20^{\circ} \mathrm{C}$. Biomass for chemotaxonomic and molecular genetic studies was prepared as described previously (Zhang et al., 2002).

The colonial and micromorphological properties of the isolate were observed using standard procedures following inoculation on modified Sauton's agar plates for 7 days at $28{ }^{\circ} \mathrm{C}$. The remaining phenotypic tests were determined using procedures described by Zhang et al. (2003).

Standard procedures were used for the extraction and analysis of the diagnostic isomers of diaminopimelic acid $\left(\mathrm{A}_{2} \mathrm{pm}\right.$; Hasegawa et al., 1983), mycolic acids (Minnikin et al., 1975), polar lipids (Minnikin et al., 1984) and wholeorganism sugars (Lechevalier \& Lechevalier, 1980), using appropriate controls. Isoprenoid quinones were extracted and purified after Collins et al. (1987); purified menaquinones were determined by reverse-phase HPLC (Wu et al., 1989). The fatty acids were extracted, purified, methylated and quantified by GC using the standard MIDI (Microbial Identification) system (Sasser, 1990; Kämpfer \& Kroppenstedt, 1996).

Genomic DNA extraction, PCR-mediated amplification of the 16S rRNA gene and purification of the PCR product from strain $276^{T}$ were carried out after Rainey et al. (1996) and the purified PCR product was sequenced directly using the method of Lu et al. (2001). The resultant 16S rRNA gene sequence was aligned manually with corresponding sequences of representatives of the genera classified in the 
suborder Corynebacterineae, including all of the type strains of Nocardia species, retrieved from the DDBJ/EMBL/ GenBank databases using the CLUSTAL X 1.8 program (Thompson et al., 1997). Phylogenetic trees were generated using the least-squares, maximum-likelihood and neighbourjoining algorithms from the PHYLIP suite of programs (Felsenstein, 1993). Evolutionary distance matrices for the least-squares and neighbour-joining methods were generated after Kimura (1980). The topologies of the resultant unrooted trees were evaluated by bootstrap analyses of the neighbour-joining dataset, based on 1000 resamplings, using the SEQBOOT and CONSENSE options from the PHYLIP package.

Chromosomal DNA, extracted from biomass of strain $276^{\mathrm{T}}$ following growth of the organism in modified Sauton's broth for 3 days at $28^{\circ} \mathrm{C}$, was purified using established procedures (Saito \& Miura, 1963; Whipple et al., 1987). The $\mathrm{G}+\mathrm{C}$ content of the DNA was determined using the thermal denaturation method (Marmur \& Doty, 1962) with Escherichia coli AS 1.365 as control. The extent of DNADNA relatedness between strain $276^{\mathrm{T}}$ and Nocardia abscessus DSM $44432^{\mathrm{T}}$ and Nocardia asteroides ATCC $19247^{\mathrm{T}}$ was determined from the DNA-DNA liquid reassociation rate (De Ley et al., 1970; Huß et al., 1983) using a UV-1206 spectrophotometer (Shimadzu) fitted with a TB- 85 thermal controller and standard software (Jahnke, 1992); the results were expressed as the mean of two determinations.

Comparison of the almost complete $16 \mathrm{~S}$ rRNA gene sequence (1411 nt) of isolate $276^{\mathrm{T}}$ with those of representatives of the genera classified in the suborder Corynebacterineae show that it contains all of the signature nucleotides expected for members of this taxon (Stackebrandt et al., 1997) and, more specifically, those characteristic of members of the family Nocardiaceae (Stackebrandt et al., 1997) and the genus Nocardia (Chun \& Goodfellow, 1995). The high 16S rRNA gene sequence similarities found between the tested organism and representatives of the species of the genus Nocardia with validly published names, namely $95 \cdot 1-98 \cdot 2 \%$, provide further evidence of its assignment to this taxon.

Strain $276^{\mathrm{T}}$ has phenotypic properties typical of members of the genus Nocardia (Goodfellow et al., 1999; Wang et al., 2004). The organism is an aerobic, Gram-positive, slightly acid-alcohol-fast actinomycete which forms an extensively branched substrate mycelium that fragments into irregular, non-motile, coccoid and rod-shaped elements and which supports sparse to abundant white aerial hyphae on modified Sauton's agar. Whole-organism hydrolysates were rich in meso- $\mathrm{A}_{2} \mathrm{pm}$, arabinose and galactose (wall chemotype IV sensu Lechevalier \& Lechevalier, 1970) and contained major amounts of diphosphatidylglycerol, phosphatidylethanolamine, phosphatidylinositol and phosphatidylinositol mannosides (phospholipid type II sensu Lechevalier et al., 1977). The isolate also contained predominant amounts of hexahydrogenated menaquinone with eight isoprene units in which the two terminal isoprene moieties were cyclized; this menaquinone is characteristic of members of the genera Nocardia and Skermania (Chun et al., 1997; Goodfellow et al., 1999). One-dimensional TLC of whole-organism acid methanolysates revealed the presence of a lower spot that corresponded to mycolic acids and a higher one corresponding to non-hydroxylated fatty acids. The mycolic acids of the tested strain co-migrated $\left(R_{\mathrm{f}}\right.$ value around 0.47 ) with those from marker strains of Nocardia. The non-hydroxylated fatty acid profile consisted of straight-chain saturated, unsaturated and 10-methylbranched components.

It is apparent from Fig. 1 that strain $276^{\mathrm{T}}$ forms a distinct phyletic line within the $16 \mathrm{~S}$ rRNA Nocardia gene tree. The organism is most closely related to the type strains of $N$. abscessus and N. asteroides. It shares $98 \cdot 2 \% 16 \mathrm{~S}$ rRNA gene sequence similarity with the type strain of N. abscessus and $97.9 \%$ with that of $N$. asteroides, values that correspond respectively to 25 and $29 \mathrm{nt}$ differences at 1411 positions. Much higher 16S rRNA gene sequence similarities have been recorded between representatives of several Nocardia species with validly published names that have DNA-DNA relatedness values well below the $70 \%$ cut-off point recommended for the delineation of genomic species by Wayne et al. (1987). The type strains of Nocardia cerradoensis and Nocardia veterana, for instance, share a 16S rRNA gene sequence similarity of $99 \%$ and have a DNA-DNA relatedness value of $58 \%$ (Albuquerque de Barros et al., 2003). In the present study, strain $276^{\mathrm{T}}$ showed a mean DNA-DNA relatedness value of $39 \%$ with $N$. abscessus DSM $44432^{\mathrm{T}}$ and $35 \%$ with N. asteroides ATCC $19247^{\mathrm{T}}$. A range of phenotypic properties separated strain $276^{\mathrm{T}}$ from the type strains of phylogenetically close species (Table 1).

It is evident from the combination of genotypic and phenotypic data that strain $276^{\mathrm{T}}$ can be distinguished from all species of Nocardia with validly published names; hence, it is proposed that it be classified in the genus Nocardia as Nocardia xishanensis sp. nov.

\section{Description of Nocardia xishanensis sp. nov.}

Nocardia xishanensis (xi.shan.en'sis. N.L. fem. adj. xishanensis referring to Xishan Mountain, the source of the soil from which the type strain was isolated).

Aerobic, Gram-positive, catalase-positive, slightly acidalcohol-fast, non-motile actinomycete that forms an extensively branched substrate mycelium which fragments in situ into coccoid and rod-shaped elements. A yellow to orange substrate mycelium carries sparse to abundant, white aerial hyphae on modified Sauton's agar. Diffusible pigments are not formed. Colony elevation is convex to irregular and colony margins are filamentous. Nitrate is reduced and aesculin, arbutin and urea are hydrolysed. Tweens 20, 60 and 80 are degraded, but not adenine, casein, elastin, guanine, hypoxanthine, starch, tyrosine or xanthine. Growth occurs between 22 and $38^{\circ} \mathrm{C}$ and from pH $5 \cdot 5$ to 10 . Chemotaxonomic properties are typical of 


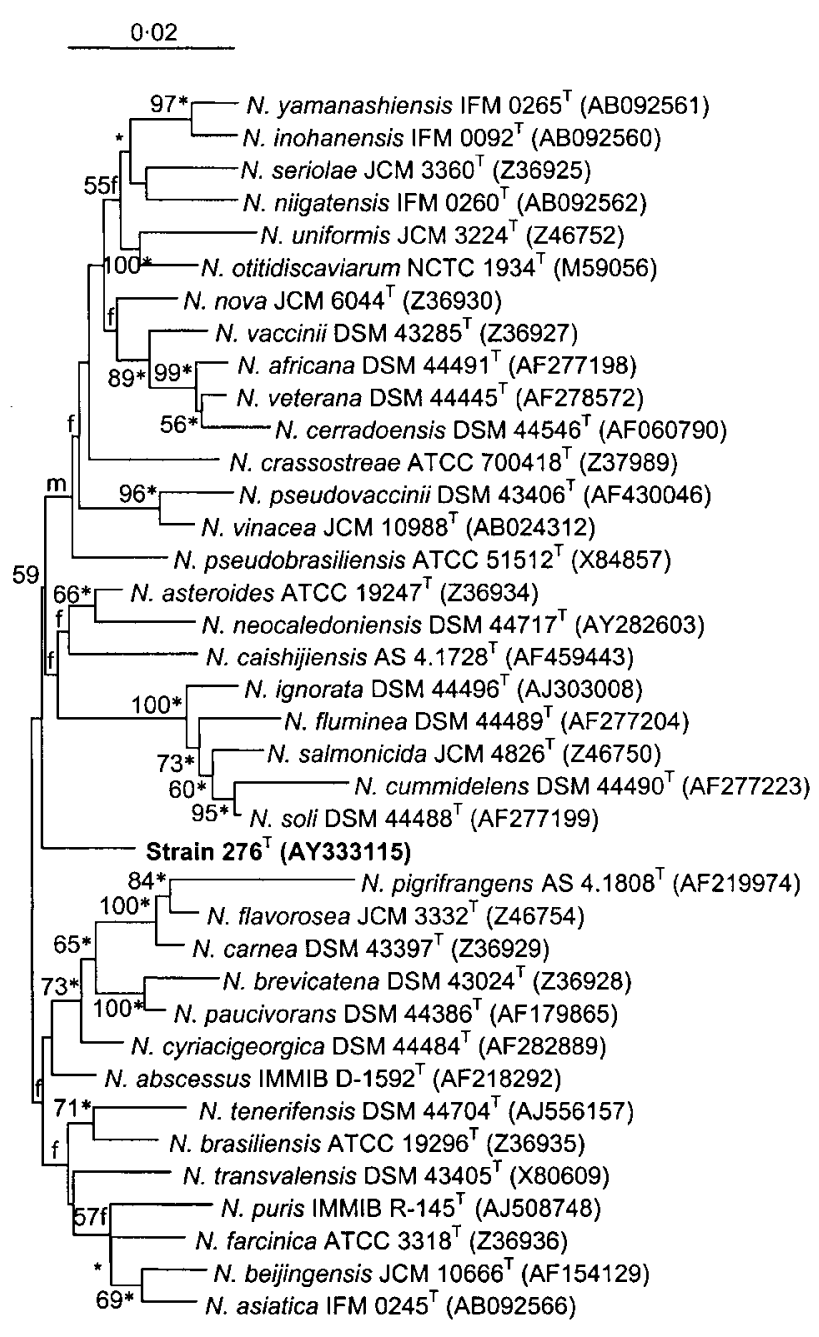

Fig. 1. Neighbour-joining tree based on nearly complete $16 \mathrm{~S}$ rRNA gene sequences showing relationships between strain $276^{\top}$ and representatives of species of Nocardia with validly published names. Asterisks indicate branches of the tree that were also recovered using the least-squares and maximumlikelihood tree-making algorithms. The symbols $f$ and $m$ denote branches of the tree that were also recovered using the leastsquares and maximum-likelihood methods, respectively. Numbers at nodes indicate levels of bootstrap support based on a neighbour-joining analysis of 1000 resampled datasets; only values above $50 \%$ are given. The scale bar indicates 0.02 substitutions per nucleotide position.

Nocardia. Acid is formed from (+)-D-glucose and glycerol but not from arbutin, $(+)$-D-cellobiose, $(+)$-D-fructose, $(+)$-D-galactose, meso-inositol, inulin, (+)-D-maltose, (+)-D-mannose, (+)-D-melezitose, (+)-D-melibiose, $(+)$-D-raffinose, $\alpha$-L-rhamnose, $(-)$-D-ribose, starch, $(+)$-D-sucrose, $\quad(+)$-D-trehalose, $(+)$-D-turanose or $(+)$-D-xylose. $(+)$-D-Cellobiose, $(+)$-D-fructose, $(+)$-Dfucose, $\quad(+)$-D-galactose, (+)-D-glucose, glycerol, meso-inositol (weak), (+)-D-maltose, $(+)$-D-mannose (weak), (+)-D-melibiose, $\alpha$-L-rhamnose, (-)-D-ribose,
Table 1. Phenotypic properties that distinguish strain $276^{\top}$ from representatives of phylogenetically close Nocardia species

Strains: 1, strain $276^{\mathrm{T}} ; 2$, N. abscessus DSM $44432^{\mathrm{T}} ; 3, N$. asteroides ATCC $19247^{\mathrm{T}}$; 4, Nocardia beijingensis JCM $10666^{\mathrm{T}} ; 5$, Nocardia cyriacigeorgica DSM $44484^{\mathrm{T}}$; 6 , Nocardia otitidiscaviarum NCTC $1934^{\mathrm{T}} ; 7$, Nocardia paucivorans DSM $44386^{\mathrm{T}} ; 8$, Nocardia pseudobrasiliensis ATCC $51512^{\mathrm{T}}$. Data were taken from this and previous studies (Yassin et al., 2000, 2001b; Zhang et al., 2003). + , Positive; -, negative; ND, not determined. All strains are positive for urea hydrolysis and grow on $0 \cdot 1 \%(\mathrm{w} / \mathrm{v})$ sodium acetate.

\begin{tabular}{|c|c|c|c|c|c|c|c|c|}
\hline Property & 1 & 2 & 3 & 4 & 5 & 6 & 7 & 8 \\
\hline \multicolumn{9}{|l|}{ Biochemical tests: } \\
\hline Aesculin hydrolysis & + & - & + & + & + & + & - & + \\
\hline Arbutin hydrolysis & + & + & + & - & ND & + & + & - \\
\hline Nitrate reduction & + & + & + & + & + & + & + & - \\
\hline \multicolumn{9}{|l|}{ Decomposition of $(\%, \mathrm{w} / \mathrm{v})$ : } \\
\hline Adenine $(0 \cdot 4)$ & - & - & - & - & - & - & - & + \\
\hline Casein $(1 \cdot 0)$ & - & - & - & - & - & - & - & + \\
\hline Elastin $(0 \cdot 3)$ & - & - & - & - & - & - & - & + \\
\hline Hypoxanthine $(0 \cdot 4)$ & - & - & - & - & - & + & - & + \\
\hline Tyrosine $(0 \cdot 5)$ & - & - & - & - & - & - & - & + \\
\hline Xanthine $(0 \cdot 4)$ & - & - & - & + & - & + & - & - \\
\hline \multicolumn{9}{|c|}{ Growth on sole carbon sources $(\%, \mathrm{w} / \mathrm{v})$ : } \\
\hline$(+)$-D-Cellobiose $(1 \cdot 0)$ & + & - & - & + & - & - & - & ND \\
\hline$(+)$-D-Galactose $(1 \cdot 0)$ & + & - & - & + & - & - & - & + \\
\hline$(+)$-D-Maltose $(1 \cdot 0)$ & + & + & - & + & - & - & - & ND \\
\hline$(+)$-D-Mannitol $(1 \cdot 0)$ & - & - & + & + & - & + & - & + \\
\hline$\alpha$-L-Rhamnose $(1 \cdot 0)$ & + & + & - & + & - & - & - & - \\
\hline$(+)$-D-Sorbitol $(1 \cdot 0)$ & + & - & - & + & - & - & - & + \\
\hline Sodium citrate $(0 \cdot 1)$ & - & + & + & + & - & - & - & + \\
\hline Growth at $45^{\circ} \mathrm{C}$ & - & - & - & - & - & + & - & - \\
\hline
\end{tabular}

(+)-D-salicin, (+)-D-sorbitol (weak), starch (weak), (+)-D-sucrose, (+)-D-trehalose, acetate, adipic acid, fumarate, lactate, malate, paraffin, pyruvate and succinate are used as sole carbon and energy sources, but not adonitol, (+)-L-arabinose, (+)-D-arabitol, arbutin, dulcitol, meso-erythritol, ethanol, glycogen, inulin, (+)-D-lactose, $(+)$-D-mannitol, (+ )-D-melezitose, methyl $\alpha$-D-glucoside, (+)-D-raffinose, xylitol, (+)-D-xylose, benzoate, citrate, formate, hippurate, malonate, sebacic acid, oxalate or tartrate. L-Alanine, L-proline and L-valine are used as sole carbon and nitrogen sources but not acetamide, L-asparagine, L-aspartate, gelatin, D-glucosamine, L-leucine, L-phenylalanine or L-serine. Growth occurs in the presence of sodium chloride at $3 \%, \mathrm{w} / \mathrm{v}$ but not at $5 \%$, w/v. Resistance is shown to lysozyme, gentamicin sulphate $\left(10 \mu \mathrm{g} \mathrm{ml}^{-1}\right)$ and penicillin $\mathrm{G}(10 \mathrm{U})$, but not to chloramphenicol $\left(30 \mu \mathrm{g} \mathrm{ml}^{-1}\right)$, erythromycin $\left(15 \mu \mathrm{g} \mathrm{ml}^{-1}\right)$, midecamycin $\left(15 \mu \mathrm{g} \mathrm{ml}^{-1}\right)$, minocycline hydrochloride $\left(30 \mu \mathrm{g} \mathrm{ml}^{-1}\right)$, rifampicin $\left(5 \mu \mathrm{g} \mathrm{ml}^{-1}\right), \quad$ streptomycin sulphate $\left(10 \mu \mathrm{g} \mathrm{ml}^{-1}\right)$, tobramycin sulphate $\left(10 \mu \mathrm{g} \mathrm{ml}^{-1}\right)$ or vancomycin hydrochloride $\left(30 \mu \mathrm{g} \mathrm{ml}^{-1}\right)$. The fatty acid profile is composed of $\mathrm{C}_{16: 0}(33 \cdot 1 \%), \mathrm{C}_{18: 0}(7 \cdot 6 \%)$, 
cis-9- $\mathrm{C}_{18: 1}(32 \cdot 7 \%)$ and 10 -methyl- $\mathrm{C}_{18: 0}(11 \cdot 3 \%)$. The $\mathrm{G}+\mathrm{C}$ content of the DNA is $68 \cdot 8 \mathrm{~mol} \%$.

The type strain, $276^{\mathrm{T}}\left(=\mathrm{CGMCC} 4.1860^{\mathrm{T}}=\mathrm{JCM} 12160^{\mathrm{T}}\right)$, was isolated from a soil sample collected from Xishan Mountain, Beijing, China. The species description is based on a single strain and hence serves as the description of the species.

\section{Acknowledgements}

This work was supported through the Royal Society-Chinese Academy of Sciences Exchange Scheme (grant no. Q814) and by the University Basic Fund of Beijing Institute of Technology of China (grant no. BITUBF-200306C08). The authors are grateful to Dr T. Kudo (JCM) and Professor R. M. Kroppenstedt (DSMZ) for providing some of the type strains of Nocardia species. We also thank Dr Yajun Song for carrying out the quantitative fatty acid analysis.

\section{References}

Albuquerque de Barros, E. V. S., Manfio, G. P., Ribeiro Maitan, V., Mendes Bataus, L. A., Kim, S. B., Maldonado, L. \& Goodfellow, M. (2003). Nocardia cerradoensis sp. nov., a novel isolate from Cerrado soil in Brazil. Int J Syst Evol Microbiol 53, 29-33.

Chun, J. \& Goodfellow, M. (1995). A phylogenetic analysis of the genus Nocardia with 16S rRNA gene sequences. Int J Syst Bacteriol 45, 240-245.

Chun, J., Blackall, L. L., Kang, S.-O., Hah, Y. C. \& Goodfellow, M. (1997). A proposal to reclassify Nocardia pinensis Blackall et al. as Skermania piniformis gen. nov., comb. nov. Int J Syst Bacteriol 47, 127-131.

Collins, M. D., Howarth, O. W., Grund, E. \& Kroppenstedt, R. M. (1987). Isolation and structural determination of new members of the vitamin $\mathrm{K}_{2}$ series in Nocardia brasiliensis. FEMS Microbiol Lett 41, 35-39.

De Ley, J., Cattoir, H. \& Reynaerts, A. (1970). The quantitative measurements of DNA hybridization from renaturation rates. Eur J Biochem 12, 133-142.

Felsenstein, J. (1993). PHYLIP (Phylogeny Inference Package), version 3.6. Distributed by the author. Department of Genetics, University of Washington, Seattle, USA.

Goodfellow, M., Isik, K. \& Yates, E. (1999). Actinomycete systematics: an unfinished synthesis. Nova Acta Leopold NF 80 (312), 47-82.

Hamid, M. E., Maldonado, L., Sharaf Eldin, G. S., Mohamed, M. F., Saeed, N. S. \& Goodfellow, M. (2001). Nocardia africana sp. nov., a new pathogen isolated from patients with pulmonary infections. $J$ Clin Microbiol 39, 625-630.

Hasegawa, T., Takizawa, M. \& Tanida, S. (1983). A rapid analysis for chemical grouping of aerobic actinomycetes. J Gen Appl Microbiol 29, 319-322.

Huß, V. A. R., Festl, H. \& Schleifer, K. H. (1983). Studies on the spectrophotometric determination of DNA hybridization from renaturation rates. Syst Appl Microbiol 4, 184-192.

Isik, K., Chun, J., Hah, Y. C. \& Goodfellow, M. (1999). Nocardia uniformis nom. rev. Int J Syst Bacteriol 49, 1227-1230.

Jahnke, K.-D. (1992). Basic computer program for evaluation of spectroscopic DNA renaturation data from a Gilford System 2600 spectrophotometer on a PC/XT/AT type personal computer. J Microbiol Methods 15, 61-73.
Kageyama, A., Poonwan, N., Yazawa, K., Mikami, Y. \& Nishimura, K. (2004a). Nocardia asiatica sp. nov., isolated from patients with nocardiosis in Japan and clinical specimens from Thailand. Int J Syst Evol Microbiol 54, 125-130.

Kageyama, A., Yazawa, K., Nishimura, K. \& Mikami, Y. (2004b). Nocardia inohanaensis sp. nov., Nocardia yamanashiensis sp. nov. and Nocardia niigatensis sp. nov. isolated from clinical specimens. Int J Syst Evol Microbiol 54, 563-569.

Kämpfer, P. \& Kroppenstedt, R. M. (1996). Numerical analysis of fatty acid patterns of coryneform bacteria and related taxa. Can J Microbiol 42, 989-1005.

Kimura, M. (1980). A simple method for estimating evolutionary rates of base substitutions through comparative studies of nucleotide sequences. J Mol Evol 16, 111-120.

Kinoshita, N., Homma, Y., Igarashi, M., Ikeno, S., Hori, M. \& Hamada, M. (2001). Nocardia vinacea sp. nov. Actinomycetologica 15, $1-5$.

Lechevalier, H. A. \& Lechevalier, M. P. (1970). Chemical composition as a criterion in the classification of aerobic actinomycetes. Int $J$ Syst Bacteriol 20, 435-443.

Lechevalier, M. P. \& Lechevalier, H. A. (1980). The chemotaxonomy of actinomycetes. In Actinomycete Taxonomy, Special Publication 6, pp. 227-291. Arlington, VA: Society for Industrial Microbiology.

Lechevalier, M. P., De Bièvre, C. \& Lechevalier, H. A. (1977) Chemotaxonomy of aerobic actinomycetes: phospholipid composition. Biochem Syst Ecol 5, 249-260.

Lu, Z., Liu, Z., Wang, L., Zhang, Y., Qi, W. \& Goodfellow, M. (2001). Saccharopolyspora flava sp. nov. and Saccharopolyspora thermophila sp. nov., novel actinomycetes from soil. Int J Syst Evol Microbiol 51, 319-325.

Maldonado, L., Hookey, J. V., Ward, A. C. \& Goodfellow, M. (2000). The Nocardia salmonicida clade, including descriptions of Nocardia cummidelens sp. nov., Nocardia fluminea sp. nov. and Nocardia soli sp. nov. Antonie van Leeuwenhoek 78, 367-377.

Marmur, J. \& Doty, P. (1962). Determination of base composition of deoxyribonucleic acid from its denaturation temperature. J Mol Biol 5, 109-118.

Minnikin, D. E., Alshamaony, L. \& Goodfellow, M. (1975). Differentiation of Mycobacterium, Nocardia and related taxa by thin-layer chromatographic analysis of whole-organism methanolysates. J Gen Microbiol 88, 200-204.

Minnikin, D. E. O'Donnell A. G., Goodfellow, M., Alderson, G., Athalye, M., Schaal, A. \& Parlett, J. H. (1984). An integrated procedure for the extraction of bacterial isoprenoid quinones and polar lipids. J Microbiol Methods 2, 233-241.

Mordarska, H., Mordarski, M. \& Goodfellow, M. (1972). Chemotaxonomic characters and classification of some nocardioform bacteria. J Gen Microbiol 71, 77-86.

Orchard, V. A. (1981). The ecology of Nocardia and related taxa. Zentbl Bakteriol Suppl 11, 167-180.

Orchard, V. A. \& Goodfellow, M. (1980). Numerical classification of some named strains of Nocardia asteroides and related isolates from soil. J Gen Microbiol 118, 295-312.

Rainey, F. A., Ward-Rainey, N., Kroppenstedt, R. M. \& Stackebrandt, E. (1996). The genus Nocardiopsis represents a phylogenetically coherent taxon and a distinct actinomycete lineage: proposal of Nocardiopsiaceae fam. nov. Int J Syst Bacteriol 46, 28-96.

Saito, H. \& Miura, K.-I. (1963). Preparation of transforming deoxyribonucleic acid by phenol treatment. Biochim Biophys Acta 72, 619-629. 
Sasser, M. (1990). Identification of bacteria by gas chromatography of cellular fatty acids. Technical Note 101. Newark, DE: Microbial ID.

Stackebrandt, E., Rainey, F. A. \& Ward-Rainey, N. L. (1997). Proposal for a new hierarchic classification system, Actinobacteria classis nov. Int J Syst Bacteriol 47, 479-491.

Thompson, J. D., Gibson, T. J., Plewniak, F., Jeanmougin, F. \& Higgins, D. G. (1997). The CLUSTAL $X$ windows interface: flexible strategies for multiple sequence alignment aided by quality analysis tools. Nucleic Acids Res 25, 4876-4882.

Wang, Y., Zhang, Z., Ruan, J., Wang, Y. \& Ali, S. (1999). Investigations of actinomycete diversity in the tropical rainforests of Singapore. J Ind Microbiol Biotechnol 23, 178-187.

Wang, L., Zhang, Y., Huang, Y., Maldonado, L. A., Liu, Z. \& Goodfellow, M. (2004). Nocardia pigrifrangens sp. nov., a novel actinomycete isolated from a contaminated plate. Int J Syst Evol Microbiol 54, 1683-1686.

Wayne, L. G., Brenner, D. J., Colwell, R. R. \& 9 other authors (1987). International Committee on Systematic Bacteriology. Report of the ad hoc committee on reconciliation of approaches to bacterial systematics. Int J Syst Bacteriol 37, 463-464.

Whipple, D. L., Le Febvre, R. B., Andrews, R. E., Jr \& Thiermann, A. B. (1987). Isolation and analysis of restriction endonuclease digestive patterns of chromosomal DNA from Mycobacterium paratuberculosis and other Mycobacterium species. J Clin Microbiol 25, 1511-1515.

Wu, C., Lu, X., Qin, M., Wang, Y. \& Ruan, J. (1989). Analysis of menaquinone compound in microbial cells by HPLC. Microbiology (English translation of Mikrobiologiya) 16, 176-178.

Yassin, A. F., Rainey, F. A., Mendroch, U., Brzezinka, H. \& Schaal, K. P. (2000). Nocardia abscessus sp. nov. Int J Syst Evol Microbiol 50, 1487-1493.

Yassin, A. F., Rainey, F. A. \& Steiner, U. (2001a). Nocardia cyriacigeorgici sp. nov. Int J Syst Evol Microbiol 51, 1419-1423.

Yassin, A. F., Rainey, F. A. \& Steiner, U. (2001b). Nocardia ignorata sp. nov. Int J Syst Evol Microbiol 51, 2127-2131.

Yassin, A. F., Sträubler, B., Schumann, P. \& Schaal, K. P. (2003). Nocardia puris sp. nov. Int J Syst Evol Microbiol 53, 1595-1599.

Zhang, J., Zhang, Y., Xiao, C., Liu, Z. \& Goodfellow, M. (2002). Rhodococcus maanshanensis sp. nov., a novel actinomycete from soil. Int J Syst Evol Microbiol 52, 2121-2126.

Zhang, J., Liu, Z. \& Goodfellow, M. (2003). Nocardia caishijiensis sp. nov., a novel soil actinomycete. Int J Syst Evol Microbiol 53, 999-1004. 